Short communication

\title{
Optimizing biomethane production from anaerobic degradation of Scenedesmus spp. biomass harvested from algae-based swine digestate treatment
}

\author{
Simone Perazzoli ${ }^{a}$, Bruna M. Bruchez ${ }^{b}$, William Michelon ${ }^{a}$, Ricardo L.R. Steinmetz ${ }^{c}$, \\ Melissa P. Mezzari ${ }^{\mathrm{d}}$, Estela O. Nunes ${ }^{\mathrm{e}}$, Marcio L.B. da Silva ${ }^{\text {c, }}{ }^{*}$ \\ ${ }^{a}$ Federal University of Santa Catarina, Department of Chemical Engineering, 88034-001, Florianópolis, Santa Catarina, Brazil \\ ${ }^{\mathrm{b}}$ West University of Santa Catarina, Bioenergy Engineering, 89820-000, Xanxerê, Santa Catarina, Brazil \\ ${ }^{c}$ Embrapa Swine and Poultry, 89700-000, Concórdia, Santa Catarina, Brazil \\ ${ }^{\mathrm{d}}$ West University of Santa Catarina, Biotechnology and Sciences Program, 89560-000, Videira, Santa Catarina, Brazil \\ e Embrapa Soybean, 86001-970, Londrina, Parana, Brazil
}

\section{A R T I C L E I N F O}

Article history:

Received 3 December 2015

Received in revised form

28 December 2015

Accepted 29 December 2015

Available online 9 January 2016

\section{Keywords:}

Biomethane

Microalgae

Phycoremediation

Swine wastewater

\begin{abstract}
A B S T R A C T
The objective of this work was to quantify biomethane from anaerobic degradation of microalgae biomass harvested from a field-scale tank reactor simulating phycoremediation of swine wastewater. The effects of nutrients starvation on microalgae chemical cellular composition changes and its influence on biomethane generation potential were also addressed. Microalgae polyculture was dominated by uncultured Scenedesmus clone BF 063 which showed a carbohydrate, protein and lipid content of 27.6 \pm 3.3 , $57.6 \pm 0.1$ and $3.9 \pm 0.6 \%$, respectively. After 25 days exposed to $\mathrm{N}$ - and P-free medium, microalgae biomass composition showed $54.6 \pm 2.6,24.1 \pm 2.4$ and $16.9 \pm 0.8 \%$ of carbohydrate, protein and lipid, respectively. Volatile solids concentration in the biomass harvested from $\mathrm{N}$ - and P-rich medium was lower $\left[67 \pm 1.7 \mathrm{~g}\right.$ VS ( $\mathrm{kg}$ biomass) $\left.{ }^{-1}\right]$ than biomass harvested from nutrient depleted medium $\left[204.1 \pm 3.1 \mathrm{~g}\right.$ VS (kg biomass) $\left.{ }^{-1}\right]$. Consequently, much higher biomethane production was obtained i.e., $103.5 \mathrm{~L}_{\mathrm{N}} \mathrm{CH}_{4}$ (kg biomass) ${ }^{-1}$ vs $44 \mathrm{~L}_{\mathrm{N}} \mathrm{CH}_{4}$ (kg biomass) $^{-1}$. The results suggest that biomethane production in digesters could be improved by integrating microalgae biomass harvested from algae-based swine wastewater digestate treatment.
\end{abstract}

(C) 2016 Elsevier Ltd. All rights reserved.

\section{Introduction}

Despite increasing interests on bioethanol and biodiesel production from microalgae (Hirano et al., 1997; Ho et al., 2011; Bruton et al., 2009; Singh and Olsen, 2011; Prajapati et al., 2013a), several studies point out that generation of biomethane is comparatively less complex and more cost-effective (González-Fernández et al., 2011; Dębowski et al., 2013). The significant amount of biodegradable components present in the microalgae such as

\footnotetext{
* Corresponding author. EMBRAPA, P.O. Box 321, 89700-000, Concórdia, Santa Catarina, Brazil.

E-mail addresses: simone.perazzoli@posgrad.ufsc.br (S. Perazzoli), bruna. bruchez@unoesc.edu.br (B.M. Bruchez), william.michelon@posgrad.ufsc.br (W. Michelon), ricardo.steinmetz@embrapa.br (R.L.R. Steinmetz), melissa. mezzari@unoesc.edu.br (M.P. Mezzari), estela.nunes@embrapa.br (E.O. Nunes) marcio.busi@embrapa.br (M.L.B. da Silva).
}

carbohydrates, lipids and proteins makes it a favorable substrate for anaerobic digestion and production of methane (Schenk et al., 2008; Harun et al., 2010; Lakaniemi et al., 2011; Prajapati et al., 2013a). However, several studies indicated that economic feasibility of the process is attainable when microalgae biomass are harvested from wastewater treatment processes (Harun et al., 2010; Ward et al., 2014). In this regard, algae-based tertiary treatment approaches have been reported with great success (Prajapati et al., 2013a, b), reducing or even eliminating costs associated with nutrients and water that would be otherwise required for algae growth (Kebede-Westhead et al., 2006; Yen and Brune, 2007; Chinnasamy et al., 2010; Lakaniemi et al., 2011).

Methane production from biodegradation of microalgae has been extensively studied and it is commonly reported to range

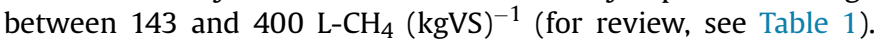
Variations in methane quantity are linked to microalgae speciesspecific differences in cellular chemical composition. For instance, 
Table 1

Biomethane production from various microalgae harvested from different growth media and culturing conditions.

\begin{tabular}{|c|c|c|c|c|c|}
\hline Microalgae & Growth medium & Fermenter type & Temperature $\left({ }^{\circ} \mathrm{C}\right)$ & $\mathrm{L}-\mathrm{CH}_{4}(\mathrm{~kg} \mathrm{vs})^{-1}$ & References \\
\hline C. vulgaris & Anaerobic sludge & Batch & 37 & 286 & Lakaniemi et al., 2011 \\
\hline Scenedesmus spp. + Chlorella spp. & Aquaculture & Semi-continuous & 35 & 143 & Yen and Brune, 2007 \\
\hline Scenedesmus spp. + Chlorella spp. + waste paper & Aquaculture & Semi-continuous & 35 & 293 & Yen and Brune, 2007 \\
\hline C. minutissima, & Synthetic & Batch & 36 & 166 & Prajapati et al., 2014 \\
\hline C. pyrenoidosa & Synthetic & Batch & 36 & 264.5 & Prajapati et al., 2014 \\
\hline C.vulgaris & Synthetic & Batch & 36 & 195 & Prajapati et al., 2014 \\
\hline C. kessleri & Synthetic & Batch & 38 & 218 & Mussgnug et al., 2010 \\
\hline Scenedesmus spp. + Chlorella spp. & Wastewater stabilization pond & Fed-batch & $35-50$ & $248-314$ & Golueke et al., 1957 \\
\hline Chlorella spp. after lipids extraction & Synthetic & Batch & 37 & $222-400$ & Ehimen et al., 2011 \\
\hline Chlorella spp. after lipids extraction & Synthetic & CSTR & $25-40$ & $188-308$ & Ehimen et al., 2011 \\
\hline Chlorella spp. after lipids extraction $\mathrm{C} / \mathrm{N}$ ratio $=8.53$ ) & Synthetic & CSTR & $25-40$ & $192-265$ & Ehimen et al., 2011 \\
\hline C. vulgaris & Synthetic & CSTR & 38 & $147-240$ & Ras et al., 2011 \\
\hline C.vulgaris & Synthetic & Fed-batch & 35 & 240 & Ras et al., 2011 \\
\hline Scenedesmus spp. & Swine digestate & Batch & 37 & 389 & This study \\
\hline Scenedesmus spp. & $\mathrm{N}$ - and P-deprived & Batch & 37 & 320 & This study \\
\hline
\end{tabular}

biodegradation of microalgae with high lipid content is expected to produce significantly more methane $\left[1014 \mathrm{~L}-\mathrm{CH}_{4}(\mathrm{kgVS})^{-1}\right]$ than protein- [851 L-CH ${ }_{4}(\mathrm{kgVS})^{-1}$ ] or carbohydrate-rich biomass [415 L$\mathrm{CH}_{4}(\mathrm{kgVS})^{-1}$ ] (Angelidaki and Sanders, 2004; Becker, 2007). The physicochemical characteristics of the growth medium play a major role on microalgae intracellular composition changes. To illustrate, the intrinsic nitrogen and phosphorous-rich characteristics of swine wastewater digestate, used as growth medium for microalgae, is likely to stimulate intracellular storage of carbohydrate and/or protein at the expenses of lipid (Michelon et al., 2015; Bruton et al., 2009; Matsui and Koike, 2010; Prajapati et al., 2013b), thus decreasing the potential of this biomass from reaching its highest methane yields. It may be possible, however, to overcome this limitation by stress-inducing changes in cellular chemical composition. Cells harvested from swine wastewater phycoremediation could be exposed to nitrogen- and phosphorusdeficient medium to induce lipid accumulation (Michelon et al., 2015; Yuan et al., 2013; Zhu et al., 2013a). These reasonably simple metabolic engineered practices were demonstrated for enhancement of biodiesel and other lipid-derived co-products (Zhu et al., 2013b; Ikaran et al., 2015). However, to the best knowledge of authors, information on how nutrients starvation and associated intracellular chemical composition changes affect microalgae biodegradability and biomethane production remains unavailable.

Therefore, the objective of this work was to quantify biomethane yield from microalgae biomass harvested from a fieldscale tank reactor simulating microalgae-based swine wastewater digestate treatment. The effects of nutrients starvation on microalgae chemical cellular composition changes were also addressed to determine whether such alterations could contribute significantly to biomethane generation potential.

\section{Material and methods}

\subsection{Microalgae}

The native microalgae consortium used in this work was obtained directly from a facultative open pond treating effluent from an upflow anaerobic sludge blanket (UASB) located at EMBRAPA swine wastewater treatment facility (Concórdia, Santa Catarina, Brazil). Optical microscopic analyses were used to provide preliminary evidences of dominant strains in the inoculum. Microalgae samples were observed under $1000 \times$ magnification (Eclipse E200 Nikon). A more precise method of microalgae identification was latter performed by targeting and sequencing 16S rRNA gene fragment from chloroplast (Mezzari et al., 2013). DNA was extracted with the MoBio ${ }^{\circledR}$ UltraClean Microbial DNA isolation kit according to manufacturer's instructions (MoBio Laboratories, Solana Beach, CA). PCR amplification of the 16S rRNA gene fragments was performed in reactions containing $500 \mathrm{nmol}$ of each universal primer 1055F 50-ATGGCTGTCGTCAGCT-30 and 1392R 50-ACGGGCGGTG TGTAC-30 primers (Ferris et al. 1996), $2 \times$ PCR Master mix (Quantifast ${ }^{\circledR}$ SYBR ${ }^{\circledR}$ Green PCR kit, Qiagen, CA, USA) and DNA template obtained from the consortium. Thermocycler conditions were: denaturation at $95{ }^{\circ} \mathrm{C}$ for $5 \mathrm{~min}$, followed by 40 cycles of $95{ }^{\circ} \mathrm{C}$ for $10 \mathrm{~s}$ and annealing at $60{ }^{\circ} \mathrm{C}$ for $30 \mathrm{~s}$. PCR products were purified with PureLink ${ }^{\circledR}$ PCR Purification Kit (Invitrogen ${ }^{\circledR}$ ) and cloned into pGEMT Easy Vector Systems (Promega ${ }^{\circledR}$ ) according to manufacturer's protocols. Cloned samples were inserted into JM109 competent cells (Promega, USA), according to manufacturer's instructions using heat shock and plated on selective Luria-Bertani (LB) medium. Colonies containing plasmids with insert were selected on X-Gal (Sigma, St. Louis, MO) and ampicillin $\left(100 \mathrm{mg} \mathrm{mL}^{-1}\right)$ medium plates. Randomly selected positive colonies were allowed to grow in liquid media for plasmidial DNA extraction using a Purelink Quick Plasmid Kit (Invitrogen, USA). Clones were subjected to sequence analysis with an ABI 3730 sequencing system, using an ABI PRISM BigDye Terminator version 3.1 cycle sequencing kit (Applied Biosystems, Foster City, CA). Sequenced products were purified with isopropanol/ethanol precipitation method prior to analysis (ABI Prism 3130 Avant sequencer, Applied Biosystems). Trimmed sequences were aligned using Ribosomal Database Project (RDP) Infernal Aligner tool. Sequences were compared to each other using Basic Local Alignment Search Tool BLAST $^{\mathbb{R}}$ (blast.ncbi.nlm.nih.gov).

\subsection{Growth}

Microalgae were first acclimated in lab scale photobioreactors under mixotrophic conditions (Mezzari et al., 2013). Microalgae was then transferred to 400 -L culturing media in 500-L circular tanks (121.2 cm Ø i.d.; $58.4 \mathrm{~cm}$ height) placed inside a greenhouse exposed to natural sunlight $\left(321.5 \pm 411.4 \mu \mathrm{mol} \mathrm{m} \mathrm{m}^{-2} \mathrm{~s}^{-1}\right)$ and controlled temperature of $30^{\circ} \mathrm{C}$. Approximately $70 \mathrm{mg} \mathrm{L}^{-1}$ of microalgae dry weight concentration was used as inoculum $(30 \% \mathrm{v} /$ $\mathrm{v})$. Experiments were batch fed using a diluted $(6 \% \mathrm{v} / \mathrm{v})$ non-sterile digestate obtained from UASB effluent. Tanks were kept under continuous agitation using submersible aquarium pumps (S300, Sarlobetter ${ }^{\circledR}$, Brazil). The effluent characteristics of the growth medium were $\left(\mathrm{g} \mathrm{L}^{-1}\right): \mathrm{pH} 7.7 \pm 0.2$, total phosphorus $(160 \pm 4.6)$, total solids $(9.8 \pm 0.2)$, total organic carbon $(1.9 \pm 0.14)$, alkalinity $\left(1.9 \pm 0.09\right.$ as $\left.\mathrm{CaCO}_{3}\right)$, ammonia- $\mathrm{N}(750.4 \pm 49.7)$, nitrite- $\mathrm{N}(4 \pm 6.8)$ and turbidity (1063 \pm 18.8 as nephelometric turbidity unit).

After 8-day following inoculation, grown microalgae 
( $\cong 200 \mathrm{mg} \mathrm{L}^{-1}$ as dry weight) was harvested by centrifugation (EVODOS, T10, Netherlands) and the collected biomass transferred to the laboratory for determination of cellular chemical composition and fermentative assays. Another batch of microalgae biomass obtained from identical cultivation method was harvested by centrifugation and re-suspended in 400-L nutrient-free freshwater. After 25 days of exposure to nutrient-free media, cells were centrifuged again and transferred to the laboratory for determination of cellular chemical composition and fermentation assays.

\subsection{Cellular chemical composition}

Biomass was oven dried (Fanem 520, BR) at $105^{\circ} \mathrm{C}$ for $5 \mathrm{~h}$. The considerably high temperature used to dry the biomass was unlikely to affect cellular composition as previously demonstrated (Guldhe et al., 2014; Bagchi et al., 2015). Lipid was determined by high temperature solvent extraction method according to AOCS Am 5-04 (AOCS, 2013). Protein content was determined by rapid combustion followed by thermal conductivity measurement in a Leco FP-528 nitrogen/protein analyzer (LECO Corporation, USA) (AOAC, 1990). Ash content was determined according to the Brazilian Compendium of Animal Nutrition, method 36 (BCAA, 2009). Carbohydrate was estimated by subtracting lipid, protein and ash content from the total biomass weight (Bi and He, 2013). Volatile solids was measured according to APHA methods (APHA, 2012).

\subsection{Theoretical methane production potential}

Theoretical methane potential (TMP) was estimated according to the model proposed by Sialve et al. (2009). The specific methane yield used to represent lipids, proteins, and carbohydrates contents were $1014 \mathrm{~L}-\mathrm{CH}_{4}(\mathrm{kgVS})^{-1}, 496 \mathrm{~L}^{-} \mathrm{CH}_{4}(\mathrm{kgVS})^{-1}$ and, $415 \mathrm{~L}_{-} \mathrm{CH}_{4}$ $\left(\mathrm{kgVS}^{-1}\right.$, respectively (Angelidaki and Sanders, 2004). TMP was estimated as follows:

$\mathrm{TMP}=\frac{1}{100}\left[\left(\mathrm{~A} \times a_{L}\right)+\left(\mathrm{B} \times b_{p}\right)+\left(\mathrm{C} \times c_{c}\right)\right]$

where: $\mathrm{A}, \mathrm{B}$ and $\mathrm{C}$ are the specific methane yields and $a_{L}, b_{P}, c_{C}$ are the dry weight $\%$ of lipid, protein and carbohydrates, respectively.

\subsection{Biomethane production}

Seeding sludge (SS) used as inoculum for biodegradation tests was prepared by mixing $1 / 3 \mathrm{v} / \mathrm{v}$ of sludge obtained from UASB (EMBRAPA wastewater treatment facility, Concordia, SC, Brazil), 1/3 $\mathrm{v} / \mathrm{v}$ sludge from UASB reactor treating wastewater effluent from a local gelatin industry, and $1 / 3 \mathrm{v} / \mathrm{v}$ fresh cattle manure. Mixing these different sources of inoculum served to warrant increased microbial diversity with a broad metabolic capability potential. The SS was kept under anaerobic conditions at $37{ }^{\circ} \mathrm{C}$, constant stirring $(60 \mathrm{rpm})$, and fed a mix of raw swine wastewater $(75 \% \mathrm{w} / \mathrm{w})$, dried and milled grass $(15 \% \mathrm{w} / \mathrm{w})$, milk powder $(5 \% \mathrm{w} / \mathrm{w})$ and vegetable oil $(5 \% \mathrm{w} / \mathrm{w})$ at loading rate of $0.3 \mathrm{~g} \mathrm{VS} \mathrm{L}^{-1}$. The inoculum used in the fermentative assays was starved for 10 days prior to beginning of the experiments to reduce the inoculum rest gas contribution (VDI, 2006).

Fermentation assays were performed according to Handbook of Verein Deutscher Ingenieure 4630 protocols (VDI, 2006). The amount of microalgae substrate used for fermentative assays was normalized to same volatile solids content among tests. All tests were conducted in triplicate using the automatic methane potential test system II (AMPTS II, Bioprocess Control, Sweden) in $500 \mathrm{~mL}$ glass reactors kept at $37^{\circ} \mathrm{C}$. Tests were conducted using microalgae biomass harvested after 8 days of cultivation and after 25 days of exposure to nutrient-free water. Negative controls were prepared using inoculum alone. Microcrystalline cellulose (Sigmacell ${ }^{\circledR}$, Sigma $^{\circledR}$, USA) was used as internal standard. Methane gas volumes were normalized to atmospheric pressure ( 1 bar), $0{ }^{\circ} \mathrm{C}$ and zero moisture content.

\subsection{Statistical analyses}

All tests were conducted in triplicate and reported data presented as mean \pm standard deviation. To determine if sets of data were significantly different from each other, data were analyzed using one-way analysis of variance (ANOVA) with OriginPro 8. Significant differences were considered at the level of $p<0.05$.

\section{Results and discussion}

Uncultured Scenedesmus clone BF 063 (97-99\% identities, accession \# KC994743.1) was dominant in the microalgae polyculture throughout the experimental time frame. The cellular composition of microalgae polyculture grown in nutrient-rich swine wastewater digestate effluent showed a carbohydrate, protein and lipid content of $27.6 \pm 3.3,57.6 \pm 0.1$ and $3.9 \pm 0.6 \%$, respectively (Fig. 1). These data were in agreement with previous reports that described carbohydrates, proteins and lipids contents in polyculture microalgae is typically within $8-56,10-52$, and 1.9-40\%, respectively (Prajapati et al., 2013a). The measured low lipid content was probably associated with high nitrogen content present in swine wastewater digestate which is a nutrient required to induce cellular storage of protein and carbohydrates at the expenses of lipids (Michelon et al., 2015; Bruton et al., 2009; Matsui and Koike, 2010; Prajapati et al., 2013a, b; Wahidin et al., 2014; Zhang et al., 2015). After 25 days of exposure to nutrient-free medium, microalgae biomass showed $54.6 \pm 2.6,24.1 \pm 2.4$ and $16.9 \pm 0.8 \%$ of carbohydrate, protein and lipid, respectively (Fig. 1). Volatile solids (VS) contents of $67 \pm 1.7$ and $204.1 \pm 3.1 \mathrm{~g} \mathrm{VS}(\mathrm{kg}$ biomass $)^{-1}$ were obtained from microalgae grown on $\mathrm{N}$ - and P-rich and $\mathrm{N}$ - and P-deficient media, respectively.

The positive experimental control using microcrystalline cellulose substrate produced a cumulative biomethane value of $385.7 \pm 12 \mathrm{~L}_{\mathrm{N}}(\mathrm{kgVS})^{-1}$, which was within the expected range [366 $\left.\mathrm{L}_{\mathrm{N}}(\mathrm{kgVS})^{-1}\right]$. According to Wang et al. (2014), this range assures

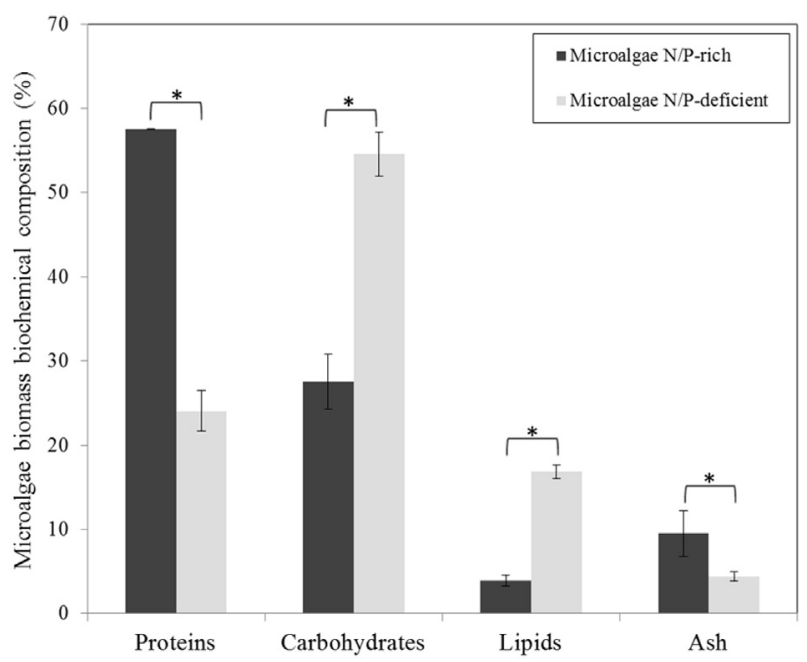

Fig. 1. Chemical composition of microalgae biomass harvested after 8 days of phycoremediation of nutrient-rich swine digestate and after 25 days of exposure to $\mathrm{N}$ - and P-free water. Asterisks indicate statistical differences $(p<0.05)$. 
effectiveness of mesophilic inoculum activity and fermentative assay accuracy. Anaerobic degradation of polyculture microalgae biomass harvested from $\mathrm{N}$ - and P-rich media, produced a total biomethane volume of $389 \pm 27 \mathrm{~L}_{\mathrm{N}}(\mathrm{kgVS})^{-1}$ [TMP of $400 \mathrm{~L}_{\mathrm{N}}$ $(\mathrm{kgVS})^{-1}$ ] (Fig. 2A). Biomethane produced by the degradation of microalgae biomass harvested from $\mathrm{N}$ - and P-deficient medium reached $320 \pm 8 \mathrm{~L}_{\mathrm{N}}(\mathrm{kgVS})^{-1}$ [TMP of $346 \mathrm{~L}_{\mathrm{N}}(\mathrm{kgVS})^{-1}$ ]. A plausible explanation for the higher methane yield per VS could be associated with high protein content verified in microalgae biomass harvested from N- and P-rich medium (Fig. 1). Proteins and lipids are known to produce significant amounts of methane however, proteins have a faster conversion rate than biodegradable complex lipids (Marsh et al., 2005; Lalak et al., 2015). This could be explained

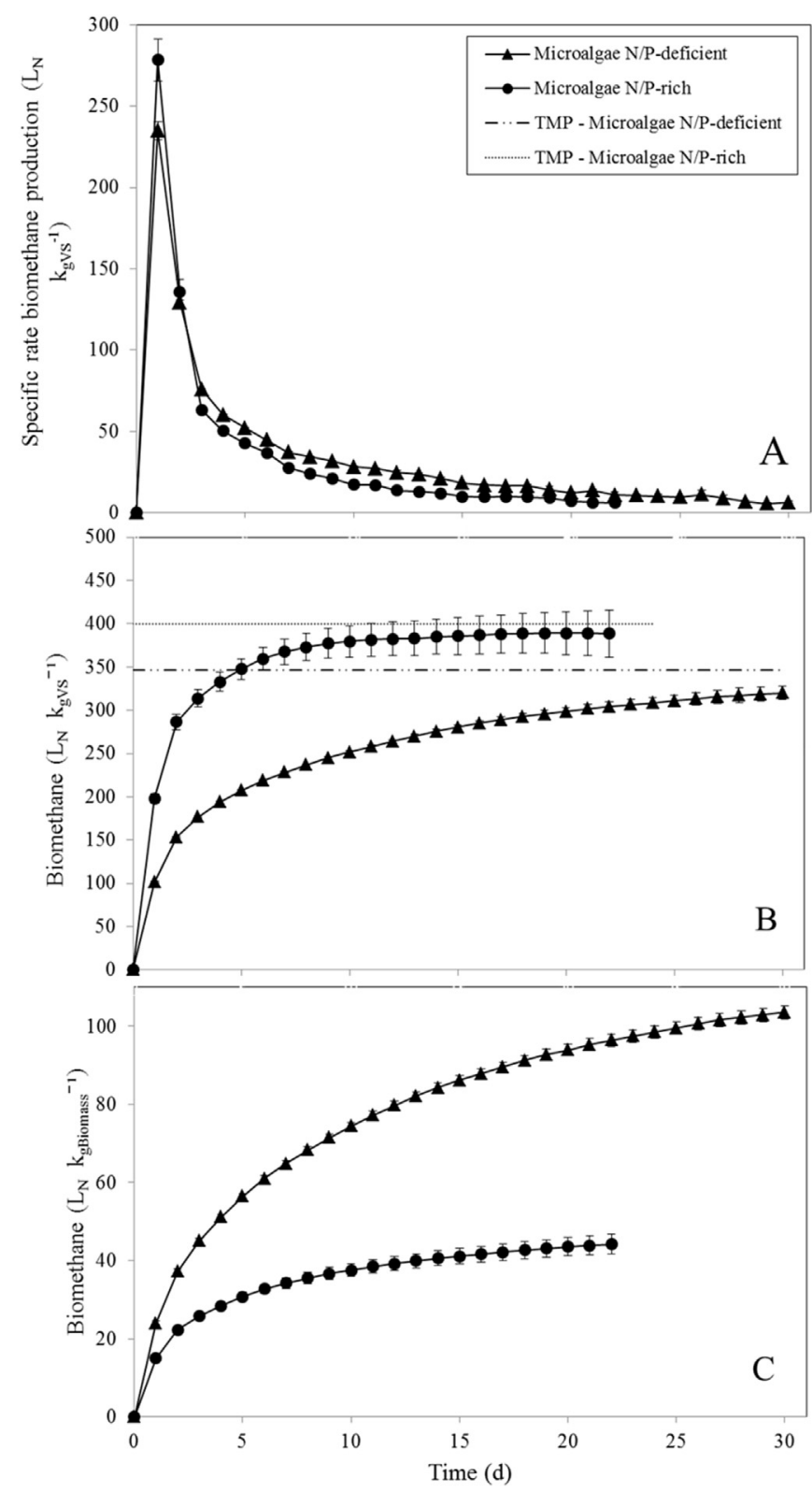

Fig. 2. Specific rate of biomethane production (A), cumulative biomethane production per volatile solid content (B) and, cumulative biomethane per gram of microalgae biomass (C) measured over time during fermentative assays using microalgae harvested after 8 days of phycoremediation of nutrient-rich swine digestate and after 25 days of exposure to N- and P-free water. Dashed lines represent TMP for both types of microalgae as substrates used in the fermentative assays.

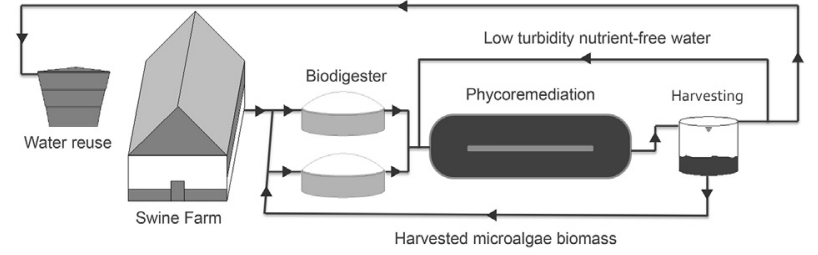

Fig. 3. Hypothetical algae-based swine wastewater treatment process coupled to anaerobic digestion.

by the difference in biomethane specific rate (Fig. 2B).

It is worth noting that the concentration of biomethane measured in this study was in the upper range of typical values described in the literature for other microalgae strains and culturing conditions (Table 1). TMP were above measured data for both substrates tested. This was expected considering that TMP is incapable to encompass the entire microorganism catabolic requirements to fully and efficiently convert all complex substrates into methane. In this case, longer retention times would be needed. This clearly emphasizes the needs for fermentative assays using site-specific substrates and inoculum sources to avoid biogas misreading at field-scale operations.

Microalgae harvested from nutrient-free medium needed extended hydraulic retention times ( $>25$ days vs $<10$ days) in order to reach full biomethane production plateau (Fig. 2A). This suggests that changes in cellular composition could be accompanied by adverse effects on microalgae biodegradability. Therefore, to enhance digestibility of algal biomass, some attempts have been made with relative success including enzymatic, chemical, mechanical and/or thermal pretreatment methods (Alzate et al., 2012; González-Fernández et al., 2012; Ho et al., 2013; Passos et al., 2014). Despite the observed enhancement in biogas production through the use of any of these methods however, the cost and energy inputs involved in such pretreatments are usually high and should be considered. Alternatively to these methods, increasing $\mathrm{C} / \mathrm{N}$ ratio in the culturing medium could also aid optimizing algae digestibility (Prajapati et al., 2014).

From operational point of view, the use of microalgae biomass harvested from algae-based swine tertiary treatment system and starved from $\mathrm{N}$ and $\mathrm{P}$ nutrients for 25 days produced considerably more biomethane (i.e., 57\%) per $\mathrm{kg}$ of microalgae biomass than microalgae biomass harvested after 8 days of phycoremediation i.e., $103.5 \pm 1.7$ vs $44 \pm 2.5{\mathrm{~L}-\mathrm{CH}_{4}}$ ( kg biomass) ${ }^{-1}$ (Fig. 2C). Fig. 3 shows a hypothetical algae-based swine wastewater treatment process integrated to anaerobic digestion. Low turbidity, nutrient-free water obtained at the end of swine wastewater phycoremediation process (Mezzari et al., 2014) could be recycled into microalgae cultivation systems for dilution of the high strength raw digestate; for inducing changes in microalgae cellular composition (Michelon et al., 2015); as well as for reuse in the farm. The harvested biomass could be added into biodigesters to increase biomethane production.

\section{Conclusions}

Biomethane was measured from anaerobic biodegradation of microalgae harvested from phycoremediation of swine-wastewater digestate. Microalgae polyculture dominated by Scenedesmus spp. grown on $\mathrm{N}$ - and P-rich swine wastewater digestate showed carbohydrate, protein and lipid content of $27.6 \pm 3.3,57.6 \pm 0.1$ and $3.9 \pm 0.6 \%$, respectively. After 25 of exposure to $\mathrm{N}$ - and P-free medium, microalgae biomass showed $54.6 \pm 2.6,24.1 \pm 2.4$ and $16.9 \pm 0.8 \%$ of carbohydrate, protein and lipid, respectively. The concentration of VS in the microalgae exposed to $\mathrm{N}$ - and P-free 
medium was three-fold higher than microalgae harvested from nutrient-rich medium. Consequently, higher biomethane yields were measured i.e., $103.5 \mathrm{~L}_{\mathrm{N}} \mathrm{CH}_{4}$ (kg biomass) ${ }^{-1}$ vs $44 \mathrm{~L}_{\mathrm{N}} \mathrm{CH}_{4}(\mathrm{~kg}$ biomass $)^{-1}$. Based on these findings, simple engineered approaches could be explored at field-scale scenarios to enable integration of algae-based swine wastewater treatment on biomethane production.

\section{Acknowledgments}

This research was supported by the Brazilian Agricultural Research Corporation (EMBRAPA) grant no. 02.12.08.004.00.05.

\section{References}

Alzate, M.E., Muñoz, R., Rogalla, F., Fdz-Polanco, F., Pérez-Elvira, S.I., 2012. Biochemical methane potential of microalgae: influence of substrate to inoculum ratio, biomass concentration and pretreatment. Bioresour. Technol. 123, 488-494. http://dx.doi.org/10.1016/j.biortech.2012.06.113.

Angelidaki, I., Sanders, W., 2004. Assessment of the anaerobic biodegradability of macropollutants. Rev. Environ. Sci. Bio Technol. 3, 117-129. http://dx.doi.org/ 10.1007/s11157-004-2502-3.

AOAC, 1990. Official Methods of Analysis of the Association of Official Analytical Chemists, fifteenth ed. Kenneth Helrich, Washington, DC.

AOCS, 2013. Official Methods and Recommended Practices of the AOCS, sixth ed. American Oil Chemists' Society, Champaign, IL.

APHA, 2012. Standard Methods for the Examination for Water and Wastewater twenty-second ed. American Water Works Association, Washington, DC.

Bagchi, S.K., Rao, P.S., Mallick, N., 2015. Development of an oven drying protocol to improve biodiesel production for an indigenous chlorophycean microalga Scenedesmus sp. Bioresour. Technol. 180, 207-213. http://dx.doi.org/10.1016/ j.biortech.2014.12.092.

BCAA, 2009. Ash or mineral matter. In: Brazilian Compendium of Animal Nutrition. São José do Rio Preto, SP, Brazil, p. 204

Becker, E.W., 2007. Micro-algae as a source of protein. Biotechnol. Adv. 25, 207-210. http://dx.doi.org/10.1016/j.biotechadv.2006.11.002.

Bi, Z., He, B.B., 2013. Characterization of microalgae for the purpose of biofuel production. Trans. ASABE 56, 1529-1539.

Bruton, T., Lyons, H., Lerat, Y., Stanley, M., Rasmussen, M.B., 2009. A review of the potential of marine algae as a source of biofuel in Ireland. Sustain. Energy Irel. Dublin, 1-88.

Chinnasamy, S., Bhatnagar, A., Claxton, R., Das, K.C., 2010. Biomass and bioenergy production potential of microalgae consortium in open and closed bioreactors using untreated carpet industry effluent as growth medium. Bioresour. Technol. 101, 6751-6760. http://dx.doi.org/10.1016/j.biortech.2010.03.094.

Dębowski, M., Zieliński, M., Grala, A., Dudek, M., 2013. Algae biomass as an alternative substrate in biogas production technologies-review. Renew. Sustain. Energy Rev. 27, 596-604. http://dx.doi.org/10.1016/j.rser.2013.07.029.

Ehimen, E.A., Sun, Z.F., Carrington, C.G., Birch, E.J., Eaton-Rye, J.J., 2011. Anaerobic digestion of microalgae residues resulting from the biodiesel production process. Appl. Energy 88, 3454-3463. http://dx.doi.org/10.1016/ j.apenergy.2010.10.020.

Ferris, M.J., Muyzer, G., Ward, D.M., 1996. Denaturing gradient gel electrophoresis profiles of 16S rRNA-defined populations inhabiting a hot spring microbial mat community. Appl. Environ. Microbiol 62, 340-346.

Golueke, C.G., Oswald, W.J., Gotaas, H.B., 1957. Anaerobic digestion of algae. Appl. Microbiol. 5, 47-55.

González-Fernández, C., Molinuevo-Salces, B., García-González, M.C., 2011. Evaluation of anaerobic codigestion of microalgal biomass and swine manure via response surface methodology. Appl. Energy 88, 3448-3453. http://dx.doi.org 10.1016/j.apenergy.2010.12.035.

González-Fernández, C., Sialve, B., Bernet, N., Steyer, J.P., 2012. Comparison of ultrasound and thermal pretreatment of Scenedesmus biomass on methane production. Bioresour. Technol. 110, 610-616. http://dx.doi.org/10.1016/ j.biortech.2012.01.043.

Guldhe, A., Singh, B., Rawat, I., Ramluckan, K., Bux, F., 2014. Efficacy of drying and cell disruption techniques on lipid recovery from microalgae for biodiese production. Fuel 128, 46-52. http://dx.doi.org/10.1016/j.fuel.2014.02.059.

Harun, R., Singh, M., Forde, G.M., Danquah, M.K., 2010. Bioprocess engineering of microalgae to produce a variety of consumer products. Renew. Sustain. Energy Rev. 14, 1037-1047. http://dx.doi.org/10.1016/j.rser.2009.11.004.

Hirano, A., Ueda, R., Hirayama, S., Ogushi, Y., 1997. $\mathrm{CO}_{2}$ fixation and ethanol production with microalgal photosynthesis and intracellular anaerobic fermentation. Energy 22, 137-142. http://dx.doi.org/10.1016/S0360-5442(96)00123-5.

Ho, S.-H., Chen, C.-Y., Lee, D.-J., Chang, J.-S., 2011. Perspectives on microalgal CO2emission mitigation systems - a review. Biotechnol. Adv. 29, 189-198. http://dx.doi.org/10.1016/j.biotechadv.2010.11.001.

Ho, S.H., Huang, S.W., Chen, C.Y., Hasunuma, T., Kondo, A., Chang, J.S., 2013. Characterization and optimization of carbohydrate production from an indigenous microalga Chlorella vulgaris FSP-E. Bioresour. Technol. 135, 157-165.
Ikaran, Z., Suárez-Alvarez, S., Urreta, I., Castañón, S., 2015. The effect of nitrogen limitation on the physiology and metabolism of Chlorella vulgaris var L3. Algal Res. 10, 134-144. http://dx.doi.org/10.1016/j.algal.2015.04.023.

Kebede-Westhead, E., Pizarro, C., Mulbry, W.W., 2006. Treatment of swine manure effluent using freshwater algae: production, nutrient recovery, and elemental composition of algal biomass at four effluent loading rates. J. Appl. Phycol. 18 41-46. http://dx.doi.org/10.1007/s10811-005-9012-8.

Lakaniemi, A.-M., Hulatt, C.J., Thomas, D.N., Tuovinen, O.H., Puhakka, J.A., 2011. Biogenic hydrogen and methane production from Chlorella vulgaris and Dunaliella tertiolecta biomass. Biotechnol. Biofuels 4, 34. http://dx.doi.org/10.1186/ 1754-6834-4-34.

Lalak, J., Kasprzycka, A., Paprota, E.M., Tys, J., Murat, A., 2015. Development of optimum substrate compositions in the methane fermentation process. Int Agrophysics 29, 313-321. http://dx.doi.org/10.1515/intag-2015-0037.

Marsh, M., Officer, C.E., Krich, K., Augenstein, D., Benemann, J., Rutledge, B., Salour, D., 2005. Biomethane from Dairy Waste a Sourcebook for the Production and Use of. Prep. West. United Dairymen. Funded part through USDA Rural Dev $1-282$.

Matsui, T., Koike, Y., 2010. Methane fermentation of a mixture of seaweed and milk at a pilot-scale plant. J. Biosci. Bioeng. 110, 558-563. http://dx.doi.org/10.1016/ j.jbiosc.2010.06.011.

Mezzari, M.P., da Silva, M.L.B., Nicoloso, R.S., Ibelli, A.M.G., Bortoli, M., Viancelli, A., Soares, H.M., 2013. Assessment of $\mathrm{N}_{2} \mathrm{O}$ emission from a photobioreactor treating ammonia-rich swine wastewater digestate. Bioresour. Technol. 149, 327-332. http://dx.doi.org/10.1016/j.biortech.2013.09.065.

Mezzari, M.P., da Silva, M.L.B., Pirolli, M., Perazzoli, S., Steinmetz, R.L.R., Nunes, E.O., Soares, H.M. 2014. Assessment of a tannin-based organic polymer to harvest Chlorella vulgaris biomass from swine wastewater digestate phycoremediation. Water Sci. Technol. 70 (5), 888-894.

Michelon, W., da Silva, M.L.B., Mezzari, M.P., Pirolli, M., Prandini, J.M., Soares, H.M., 2015. Effects of nitrogen and phosphorus on biochemical composition of microalgae polyculture harvested from phycoremediation of piggery wastewater digestate. Appl. Biochem. Biotechnol. http://dx.doi.org/10.1007/s12010015-1955-x. Online first.

Mussgnug, J.H., Klassen, V., Schlüter, A., Kruse, O., 2010. Microalgae as substrates for fermentative biogas production in a combined biorefinery concept. J. Biotechnol. 150, 51-56. http://dx.doi.org/10.1016/j.jbiotec.2010.07.030.

Passos, F., Uggetti, E., Carrère, H., Ferrer, I., 2014. Pretreatment of microalgae to improve biogas production: a review. Bioresour. Technol. 172, 403-412. http:// dx.doi.org/10.1016/j.biortech.2014.08.114.

Prajapati, S.K., Kaushik, P., Malik, A., Vijay, V.K., 2013a. Phycoremediation and biogas potential of native algal isolates from soil and wastewater. Bioresour. Technol. 135, 232-238. http://dx.doi.org/10.1016/j.biortech.2012.08.069.

Prajapati, S.K., Kaushik, P., Malik, A., Vijay, V.K., 2013b. Phycoremediation coupled production of algal biomass, harvesting and anaerobic digestion: possibilities and challenges. Biotechnol. Adv. 31, 1408-1425. http://dx.doi.org/10.1016/ j.biotechadv.2013.06.005.

Prajapati, S.K., Malik, A., Vijay, V.K., 2014. Comparative evaluation of biomass production and bioenergy generation potential of Chlorella spp. through anaerobic digestion. Appl. Energy 114, 790-797. http://dx.doi.org/10.1016/ j.apenergy.2013.08.021.

Ras, M., Lardon, L., Bruno, S., Bernet, N., Steyer, J.-P., 2011. Experimental study on a coupled process of production and anaerobic digestion of Chlorella vulgaris. Bioresour. Technol. 102, 200-206. http://dx.doi.org/10.1016/ j.biortech.2010.06.146.

Schenk, P.M., Thomas-Hall, S.R., Stephens, E., Marx, U.C., Mussgnug, J.H., Posten, C., Kruse, O., Hankamer, B., 2008. Second generation biofuels: high-efficiency microalgae for biodiesel production. BioEnergy Res. 1, 20-43. http:// dx.doi.org/10.1007/s12155-008-9008-8.

Sialve, B., Bernet, N., Bernard, O., 2009. Anaerobic digestion of microalgae as a necessary step to make microalgal biodiesel sustainable. Biotechnol. Adv. 27, 409-416. http://dx.doi.org/10.1016/j.biotechadv.2009.03.001.

Singh, A., Olsen, S.I., 2011. A critical review of biochemical conversion, sustainability and life cycle assessment of algal biofuels. Appl. Energy 88, 3548-3555. http:// dx.doi.org/10.1016/j.apenergy.2010.12.012.

VDI 4630-Fermentation of Organic Materials Characterisation of the Substrate, Sampling, Collection of Material Data, 2006. Fermentation Tests 1-92.

Wahidin, S., Idris, A., Shaleh, S.R.M., 2014. Rapid biodiesel production using wet microalgae via microwave irradiation. Energy Convers. Manag. 84, 227-233. http://dx.doi.org/10.1016/j.enconman.2014.04.034.

Wang, B., Nges, I.A., Nistor, M., Liu, J., 2014. Determination of methane yield of cellulose using different experimental setups. Water Sci. Technol. 70, 599-604. http://dx.doi.org/10.2166/wst.2014.275.

Ward, A.J., Lewis, D.M., Green, F.B., 2014. Anaerobic digestion of algae biomass: a review. Algal Res. 5, 204-214. http://dx.doi.org/10.1016/j.algal.2014.02.001.

Yen, H.-W., Brune, D.E., 2007. Anaerobic co-digestion of algal sludge and waste paper to produce methane. Bioresour. Technol. 98, 130-134. http://dx.doi.org/ 10.1016/j.biortech.2005.11.010.

Yuan, Z., Wang, Z., Takala, J., Hiltunen, E., Qin, L., Xu, Z., Qin, X., Zhu, L., 2013. Scaleup potential of cultivating Chlorella zofingiensis in piggery wastewater for biodiesel production. Bioresour. Technol. 137, 318-325.

Zhang, Y., Li, Y., Zhang, X., Tan, T., 2015. Biodiesel production by direct transesterification of microalgal biomass with co-solvent. Bioresour. Technol. 196, 712-715. http://dx.doi.org/10.1016/j.biortech.2015.07.052.

Zhu, L.D., Takala, J., Hiltunen, E., Wang, Z.M., 2013a. Recycling harvest water to 
cultivate Chlorella zofingiensis under nutrient limitation for biodiesel production. Bioresour. Technol. 144, 14-20. http://dx.doi.org/10.1016/ j.biortech.2013.06.061.
Zhu, S., Huang, W., Xu, J., Wang, Z., Xu, J., Yuan, Z., 2013b. Metabolic changes of starch and lipid triggered by nitrogen starvation in the microalga Chlorella zofingiensis. Bioresour. Technol. 152, 292-298. 